\title{
PENERAPAN MODEL PEMBELAJARAN CREATIVE PROBLEM SOLVING (CPS) UNTUK MENINGKATKAN HASIL BELAJAR MATEMATIKA SISWA KELAS X IPA 1 MAN 2 MODEL PEKANBARU
}

\author{
Oleh: ${ }^{1}$ Titi Solfitri, ${ }^{2}$ Armis \\ 1,2 Program Studi Pendidikan Matematika FKIP Universitas Riau, Pekanbaru \\ Email: ${ }^{1}$ tisolfitri@yahoo.com dan ${ }^{2}$ armis t@yahoo.com
}

\begin{abstract}
Abstrak:
Penelitian ini merupakan penelitian tindakan kelas yang bertujuan untuk meningkatkan hasil belajar matematika dengan menggunakan pembelajaran Creative Problem Solving (CPS). Subjek penelitian ini adalah seluruh siswa kelas X IPA 1 MAN 2 Model Pekanbaru, semester II T.A.2009/2010. Jumlah siswa dalam kelas tersebut ada 29 orang dengan kemampuan akademik yang heterogen. Setiap siklus terdiri dari empat tahapan yaitu perencanaan, tindakan, observasi, dan refleksi. Disetiap akhir siklus, dilakukan tes. Data dikumpulkan berdasarkan lembar observasi dan tes kemudian data dianalisis secara deskriptif naratif dan statistik deskriptif. Tindakan dikatakan berhasil apabila kualitas proses pembelajaran meningkat atau jumlah siswa yang mencapai ketuntasan belajar minimum menurun dari tes I dan II. Jumlah siswa yang mencapai ketuntasan minimum sebelum diterapkan CPS, pada tes I, dan tes II berturut-turut sebesar 34,48\%, 62,07\%, dan 65,52\%. Persentase ketuntasan minimum yang dicapai memperlihatkan gambaran bahwa pembelajaran Creative Problem Solving (CPS) dapat meningkatkan hasil belajar matematika siswa Kelas X IPA 1 MAN 2 Model Pekanbaru.
\end{abstract}

Kata Kunci: Proses pembelajaran, Hasil belajar matematika, Creative Problem Solving Strategy, Penelitian tindakan kelas

\section{Pendahuluan}

Salah satu komponen yang paling penting dari sistem pendidikan adalah kurikulum. Mulyasa (2007) berpendapat dalam upaya untuk meningkatkan mutu pendidikan salah satunya adalah dengan perubahan kurikulum. Kurikulum Tingkat Satuan Pendidikan (KTSP) merupakan paradigma baru dalam dunia pendidikan Indonesia yang diharapkan akan membawa perbaikan di dunia pendidikan. Oleh karena itu, KTSP harus dipelajari, dipahami, dan dipraktekkan dalam kehidupan nyata dunia pendidikan.

Dalam panduan penyusunan Kurikulum Tingkat Satuan Pendidikan (KTSP) oleh Badan Standar Nasional Pendidikan (BSNP) tahun 2006 dinyatakan bahwa 
matematika merupakan ilmu universal yang mendasari perkembangan teknologi modern, mempunyai peran penting dalam berbagai siswa. Sehingga salah satu alternatif untuk dapat menghadapi desakan globalisasi pendidikan adalah membekali diri dengan matematika.

Ketercapaian tujuan pembelajaran matematika dapat dilihat dari hasil belajar matematika. Hasil belajar bergantung kepada cara guru mengajar dan aktivitas siswa sebagai pembelajar. Guru sebagai pengajar sekaligus pendidik harus bisa menciptakan kondisi belajar yang menyenangkan dalam proses pembelajaran dan menerapkan model pembelajaran yang tepat sehingga siswa mampu mengembangkan potensinya dengan optimal. Dengan menerapkan model pembelajaran yang tepat diharapkan hasil belajar siswa menjadi lebih baik. Hasil belajar matematika yang diharapkan setiap sekolah adalah hasil belajar matematika yang mencapai ketuntasan belajar matematika siswa. Siswa dikatakan tuntas belajar matematika apabila nilai hasil belajar matematika siswa telah mencapai Kriteria Ketuntasan Minimal (KKM) yang ditetapkan sekolah (Depdiknas, 2006).

Pendekatan pemecahan masalah merupakan fokus dalam pembelajaran matematika yang mencakup masalah tertutup dengan solusi tunggal, masalah terbuka dengan solusi tidak tunggal, dan masalah dengan berbagai cara penyelesaian. Untuk meningkatkan kemampuan memecahkan masalah perlu dikembangkan keterampilan memahami masalah, membuat model matematika, menyelesaikan masalah, dan menafsirkan masalahnya (BSNP, 2006).

Berdasarkan kutipan diatas, jelas terlihat bahwa pendekatan pemecahan masalah merupakan fokus dalam pembelajaran matematika. Dalam setiap kesempatan, pembelajaran matematika hendaknya dimulai dengan pengenalan masalah yang sesuai dengan situasi. Dengan mengajukan masalah, peserta didik secara bertahap dibimbing untuk menguasai konsep matematika.

Kenyataannya menunjukkan tidak demikian di kelas $X$ IPA 1 MAN 2 Model Pekanbaru. Berdasarkan wawancara peneliti dengan guru bidang studi MAN 2 Model Pekanbaru, diperoleh bahwa hasil belajar matematika siswa masih rendah pada pokok bahasan trigonometri 
semester genap tahun pelajaran 2009/2010, siswa yang mencapai KKM yang ditetapkan sekolah yaitu 62 adalah 10 orang $(34,48 \%)$ dari 29 orang siswa, dan juga hasil wawancara peneliti dengan siswa MAN 2 Model terhadap proses pembelajaran matematika yang dilakukan guru, diperoleh kurangnya kemampuan siswa dalam pemecahan masalah. Saat berhadapan dengan soal-soal yang mengandung permasalahan di dalamnya, siswa cenderung bingung langkah apa yang akan dilakukan untuk menyelesaikannya. Siswa tidak terbiasa untuk merumuskan apa yang menjadi permasalahan serta membuat pemodelan matematika dari permasalahan yang diberikan dan juga siswa tidak berusaha untuk mencari dan menyerap informasi (pengetahuan) yang ada di buku. Mereka masih menunggu materi yang disampaikan oleh guru pada setiap pertemuan. Kebanyakan siswa ketika dijelaskan mengerti, namun ketika mengerjakan sendiri tidak bisa dan hanya mampu menyelesaikan masalah/ soal dengan tipe soal yang setipe dengan yang di contohkan oleh guru.

Dalam proses pembelajaran guru tetap menggunakan model pembelajaran yang diyakininya lebih efektif dalam menyampaikan pelajaran matematika, yaitu model pembelajaran langsung. Dalam proses pembelajaran guru selama ini adalah menjelaskan materi, memberikan contoh soal, memberikan latihan dan memberikan pekerjaan rumah kepada siswa. Pembelajaran seperti ini terjadi terus menerus selama pertemuan. Tidak ada upaya guru menggali kemampuan pemecahan masalah siswanya melalui soal-soal yang berbeda tipe dan mengandung masalah di dalamnya. Menurut informasi yang diperoleh dari guru tersebut, hal ini dikarenakan adanya keterbatasan waktu, sehingga soal-soal seperti ini tidak sempat untuk dibahas dalam pertemuan di kelas. Lebih jauh lagi, menurut guru tersebut pembahasan soal-soal mengandung masalah dianggap sudah dipelajari siswa secara mandiri. Kondisi ini melahirkan anggapan bagi peserta didik bahwa belajar matematika tidak lebih sekedar mengingat kemudian melupakan fakta dan konsep. Proses pembelajaran yang demikian tidak sesuai dengan tujuan pembelajaran matematika saat ini, yaitu agar siswa mampu memecahkan masalah. Sehingga jelas terdapat 
kesenjangan antara kenyataan dengan harapan.

Untuk mengatasi permasalahan di atas, maka perlu dibentuk suatu model pembelajaran yang dapat meningkatkan kemampuan siswa dalam memecahkan masalah, keterampilan memahami masalah, membuat model matematika, menyelesaikan masalah, dan menafsirkan masalahnya. Salah satu model pembelajaran yang dapat diterapkan untuk mengatasi masalah tersebut adalah model pembelajaran Creative Problem Solving (CPS). Model pembelajaran CPS adalah suatu model pembelajaran yang berpusat pada pengajaran dan keterampilan pemecahan masalah, yang diikuti dengan penguatan keterampilan (K.L. Pepkin, 2004). Berdasarkan hasil penelitian yang dilakukan oleh Adi Nur Cahyono (Program Pascasarjana Universitas Negeri Semarang, 2007) model pembelajaran CPS ini dapat menimbulkan minat sekaligus kreatifitas dan motivasi siswa dalam mempelajari matematika sehingga siswa dapat memperoleh manfaat yang maksimal, baik dari proses maupun hasil belajarnya. Berdasarkan uraian di atas, peneliti mencoba menerapkan model pembelajaran Creative Problem Solving (CPS) untuk meningkatkan hasil belajar matematika siswa kelas $X$ IPA 1 MAN 2 Model Pekanbaru pada materi pokok barisan dan deret.

Berdasarkan uraian di atas maka rumusan masalah pada penelitian ini adalah sebagai berikut: "Apakah penerapan model pembelajaran Creative Problem Solving (CPS) dapat meningkatkan hasil belajar matematika siswa kelas X IPA 1 MAN 2 Model Pekanbaru semester genap tahun pelajaran 2009/2010 pada materi pokok barisan dan deret bilangan?". Adapun tujuan penelitian ini adalah untuk meningkatkan hasil belajar matematika siswa kelas X IPA 1 MAN 2 Model Pekanbaru semester genap tahun pelajaran 2009/2010 pada materi pokok barisan dan deret bilangan melalui penerapan model pembelajaran Creative Problem Solving (CPS).

\section{Metode Penelitian}

Bentuk penelitian ini adalah penelitian tindakan kelas kolaboratif, peneliti dan guru berkolaborasi dalam penelitian. Arikunto (2008) mengemukakan bahwa 
5 | al-Khwarizmi, Volume II, Edisi 2, Oktober 2014, Hal. 1 - 14.

penelitian tindakan kelas merupakan suatu pencermatan terhadap kegiatan belajar berupa sebuah tindakan, yang sengaja dimunculkan dan terjadi dalam sebuah kelas secara bersama. Wardani (2003) mengemukakan bahwa penelitian tindakan kelas merupakan penelitian yang dilakukan oleh guru di dalam kelasnya sendiri melalui refleksi diri dengantujuan memperbaiki kinerjanya sebagai guru sehingga hasil belajar siswa meningkat. Arikunto (2008) menyatakan bahwa secara garis besar penelitian tindakan kelas dilaksanakan melalui empat tahap yang lazim dilalui, yaitu (1) perencanaan, (2) pelaksanaan, (3) pengamatan, dan (4) refleksi.

Tindakan dalam penelitian ini adalah penerapan model pembelajaran Creative Problem Solving (CPS) pada materi pokok barisan dan deret bilangan untuk meningkatkan hasil belajar matematika siswa kelas X IPA 1 MAN 2 Model Pekanbaru tahun pelajaran 2009/2010. Pelaksanaan tindakan dilakukan oleh peneliti sebagai guru, sedangkan guru bidang studi matematika sebagai pengamat selama proses pembelajaran berlangsung.

Penelitian ini dilaksanakan dalam dua siklus. Siklus pertama terdiri dari tiga kali pertemuan dan satu kali ulangan harian dan siklus kedua terdiri dari tiga kali pertemuan dan satu kali ulangan harian. Setiap siklus dalam penelitian ini melalui empat tahap, yaitu perencanaan, tindakan, pengamatan, dan refleksi. Masingmasing tahap pada setiap siklus dalam penelitian ini dapat diuraikan sebagai berikut: (1). Perencanaan (Planning). Pada tahap ini peneliti menyusun silabus, Rencana Pelaksanaan Pembelajaran (RPP), membuat Lembar Kerja Siswa (LKS), lembar pengamatan dan tes hasil belajar. (2). Pelaksanaan Tindakan (Acting). Pelaksanaan tindakan merupakan implementasi dari perencanaan. Pada tahap ini proses pembelajaran dilakukan secara terstruktur berpandu pada Rencana Pelaksanaan Pembelajaran (RPP). Siswa mendiskusikan LKS dalam kelompok heterogen dengan menerapkan model pembelajaran CPS. (3). Pengamatan (Observing). Dalam tahap ini yang bertindak sebagai pengamat utama terhadap proses pembelajaran adalah guru bidang studi matematika yang mengajar di kelas X IPA 1 MAN 2 Model Pekanbaru. Pelaksanaan observasi dilakukan sejalan dengan 
pelaksanaan tindakan. Guru melakukan pengamatan berpedoman kepada lembar pengamatan aktivitas guru dan siswa. (4). Refleksi (Reflecing). Refleksi dilakukan setelah tindakan berakhir yang merupakan perenungan bagi peneliti atas dampak dari proses pembelajaran yang dilakukan. Hasil dari refleksi dijadikan sebagai langkah untuk merencanakan tindakan baru pada pelaksanaan pembelajaran selanjutnya. Tahap ini bertujuan untuk mengkaji, melihat dan mempertimbangkan hasil atau dampak dari tindakan. Kelemahan dan kekurangan pada siklus I akan diperbaiki pada siklus II.

Terdapat instrumen penelitian yang diuraikan sebagai berikut :

1. Perangkat Pembelajaran

Perangkat pembelajaran yang digunakan pada penelitian ini adalah silabus, RPP, dan LKS.

2. Instrumen Pengumpulan Data

Data yang dikumpulkan pada penelitian ini adalah data tentang aktivitas guru dan siwa selama proses pembelajaran dan data tentang hasil belajar matematika siswa setelah proses pembelajaran. Data tentang aktivitas guru dan siswa selama proses pembelajaran dikumpulkan dengan menggunakan lembar pengamatan. Data tentang hasil belajar matematika siswa setelah proses pembelajaran dikumpulkan dengan menggunakan tes hasil belajar yang mencakup materi pokok barisan dan deret bilangan.

Teknik yang digunakan untuk mengumpulkan data dalam penelitian ini adalah teknik observasi dan tes.

1. Teknik Observasi

Teknik observasi dilakukan dengan menggunakan lembar pengamatan untuk mengamati keterlaksanaan model pembelajaran dan aktivitas serta interaksi siswa dalam kelompok. Pengamatan terhadap aktivitas guru dan siswa dalam proses pembelajaran dilakukan setiap pertemuan dengan mengisi lembar pengamatan yang disediakan. Lembar pengamatan yang disusun mengacu pada penyusunan lembar penilaian kemampuan melaksanakan perbaikan pembelajaran (tim FKIP).

2. Teknik Tes

Data tentang hasil belajar matematika siswa dikumpulkan dengan teknik tes melalui tes hasil belajar matematika 
7 | al-Khwarizmi, Volume II, Edisi 2, Oktober 2014, Hal. 1 - 14.

berupa ulangan harian pada materi pokok barisan dan deret bilangan. Ulangan harian terdiri dari ulangan harian I dan ulangan harian II. Ulangan harian I dilaksanakan setelah pertemuan ketiga dan ulangan harian II dilaksanakan setelah pertemuan ketujuh. Soal-soal ulangan harian berdasarkan indikator yang ingin dicapai pada materi pokok barisan dan deret bilangan.

Teknik yang digunakan untuk menganalisis data dalam penelitian ini adalah sebagai berikut:

1. Analisis Data Tentang Aktivitas Guru dan Siswa

Analisis data tentang aktivitas guru dan siswa didasarkan dari hasil lembar pengamatan selama pelaksanaan tindakan. Menentukan aktivitas guru dan siswa yang akan diperbaiki setiap siklus. Data tentang aktivitas guru dan siswa dianalisis secara kualitatif guna melihat kesesuaian antara perencanaan dengan pelasanaan tindakan. Pelaksanaan tindakan dikatakan sesuai jikasemua aktivitas dalam penerapan model pembelajaran CPS terlaksana sebagai mana mestinya.

2. Analisis Data Ketercapaian KKM Indikator

Analisis data ketercapaian KKM untuk setiap indikator pada materi pokok barisan dan deret bilangan dilakukan dengan menghitung persentase siswa yang mencapai KKM pada setiap indikator.

3. Analisis Keberhasilan Tindakan

Analisis data tentang hasil belajar matematika siswa pada materi pokok baris dan deret bilangan dilakukan dengan melihat perolehan nilai hasil belajar yang diperoleh secara individu yang diperoleh dari ulangan harian. Selanjutnya dibandingkan dengan KKM yang telah ditetapkan yaitu 67. Pada penelitian ini siswa dikatakan memiliki hasil belajar matematika mencapai KKM apabila perolehan nilai ulangan harian pada materi pokok barisan dan deret bilangan minimal 67.

Menurut Suyanto (1997), apabila skor hasil belajar siswa setelah tindakan lebih baik, maka dapat dikatakan bahwa tindakan berhasil. Akan tetapi, jika tidak ada bedanya dan bahkan lebih buruk maka tindakan belum berhasil. Dengan kata lain, jika hasil belajar siswa meningkat maka tindakan dikatakan berhasil. Oleh karena itu, hasil belajar matematika siswa dikatakan meningkat jika jumlah siswa yang mencapai KKM setelah tindakan 
lebih banyak dibandingkan sebelum tindakan.

\section{Hasil dan Pembahasan}

Ketuntasan hasil belajar matematika siswa untuk setiap indikator dianalisis secara individu. Siswa dikatakan mencapai KKM indikator jika memperoleh nilai lebih atau sama dengan KKM setiap indikator yang telah ditetapkan. Persentasi ketercapaian KKM pada siklus I dapat dilihat pada tabel berikut :

Tabel 1. Ketercapaian KKM Indikator pada Ulangan Harian I

\begin{tabular}{|c|l|c|c|}
\hline \multirow{2}{*}{ No } & \multirow{2}{*}{ Indikator Ketercapaian } & \multicolumn{2}{|c|}{$\begin{array}{c}\text { Siswa yang } \\
\text { Mencapai KKM }\end{array}$} \\
\cline { 3 - 4 } & Jumlah & $\begin{array}{c}\text { Persentase } \\
\text { (\%) }\end{array}$ \\
\hline 1 & $\begin{array}{l}\text { Menemukan rumus suku ke- } n \\
\text { barisan aritmetika }\end{array}$ & 25 & 86,21 \\
\hline 2 & $\begin{array}{l}\text { Menemukan suku tengah } \\
\text { barisan aritmetika }\end{array}$ & 17 & 58,62 \\
\hline 3 & $\begin{array}{l}\text { Menemukan barisan baru dari } \\
\text { penyisipan beberapa suku } \\
\text { pada }\end{array}$ & 25 & 86,21 \\
\hline 4 & $\begin{array}{l}\text { Menemukan rumus jumlah } n \\
\text { suku pertama deret aritmetika }\end{array}$ & 21 & 72,41 \\
\hline 5 & $\begin{array}{l}\text { Menemukan rumus suku ke- } n \\
\text { barisan bilangan geometri }\end{array}$ & 21 & 72,41 \\
\hline 6 & $\begin{array}{l}\text { Menemukan suku tengah } \\
\text { barisan geometri }\end{array}$ & 7 & 24,14 \\
\hline & $\begin{array}{l}\text { Menemukan barisan baru dari } \\
\text { penyisipan beberapa suku } \\
\text { pada } \\
\text { barisan geometri awal }\end{array}$ & 15 & 51,72 \\
\hline
\end{tabular}

Berdasarkan tabel 1, tidak semua siswa mencapai KKM untuk semua indikator. Hal ini disebabkan karena siswa kurang teliti mencermati soal yang diberikan dan kesalahan dalam menuliskan dan menggunakan rumus. Jumlah siswa yang belum mencapai KKM 67 adalah 11 siswa (37.93\%). Untuk ketercapaian indikator pada ulangan harian II, dapat dilihat pada tabel berikut. 
9 | al-Khwarizmi, Volume II, Edisi 2, Oktober 2014, Hal. 1 - 14.

Tabel 2. Ketercapaian KKM Indikator pada Ulangan Harian II

\begin{tabular}{|c|l|c|c|}
\hline \multirow{2}{*}{ No } & \multicolumn{2}{|c|}{ Indikator Ketercapaian } & \multicolumn{2}{|c|}{$\begin{array}{c}\text { Siswa yang } \\
\text { Mencapai KKM }\end{array}$} \\
\cline { 3 - 4 } & Jumlah & $\begin{array}{c}\text { Persentase } \\
\text { (\%) }\end{array}$ \\
\hline 1 & $\begin{array}{l}\text { Menemukan rumus jumlah } n \\
\text { suku pertama deret geometri }\end{array}$ & 19 & 65,52 \\
\hline 2 & $\begin{array}{l}\text { Mengenal bentuk deret } \\
\text { geometri tak hingga konvergen }\end{array}$ & 23 & 79,31 \\
\hline 3 & $\begin{array}{l}\text { Membuat model matematika } \\
\text { dari masalah deret aritmetika }\end{array}$ & 17 & 58,62 \\
\hline 4 & $\begin{array}{l}\text { Membuat model matematika } \\
\text { dari masalah deret geometri }\end{array}$ & 10 & 34,48 \\
\hline 5 & $\begin{array}{l}\text { Menentukan penyelesaian } \\
\text { darin masalah yang berkaitan } \\
\text { dengan deret aritmetika }\end{array}$ & 15 & 51,72 \\
\hline 6 & $\begin{array}{l}\text { Menentukan penyelesaian dari } \\
\text { masalah yang berkaitan } \\
\text { dengan deret geometri }\end{array}$ & 21 & 72,41 \\
\hline
\end{tabular}

Pada ulangan harian II seperti halnya ulangan harian I, tidak semua siswa mencapai kriteria ketuntasan untuk semua indikator. Hal ini disebabkan karena siswa kurang teliti mencermati soal yang diberikan dan kesalahan dalam menuliskan dan menggunakan rumus. Jumlah siswa yang belum mencapai KKM 67 adalah 10 orang (34,48\%).

Dengan memperhatikan kedua tabel diatas dapat dilihat bahwa pada ulangan harian I ada empat indikator dengan persentase jumlah siswa yang mencapai KKM cukup tinggi, sedangkan pada ulangan harian II persentase jumlah siswa yang mencapai KKM per indikator mencapai penurunan. Hal ini disebabkan karena siswa lebih mampu menyelesaikan soal-soal pada ulangan harian I dibandingkan dengan ulangan harian II. Pada ulangan harian II secara umum siswa kurang teliti mencermati soal yang diberikan.

Peningkatan hasil belajar dapat dilihat dari nilai matematika siswa sebelum tindakan dengan nilai matematika siswa setelah diberikan tindakan yaitu ulangan harian I dan ulangan harian II. Siswa dikatakan mencapai KKM jika memperoleh nilai lebih atau sama dengan KKM 
yang ditetapkan, yaitu 67. Keberhasilan tindakan dapat dilihat dari tabel berikut.

Tabel 3. Daftar Distribusi Frekuensi Nilai Hasil Belajar Siswa pada Skor Dasar, Ulangan Harian I dan Ulangan Harian II

\begin{tabular}{|c|c|c|c|c|}
\hline \multirow{2}{*}{ Interval } & \multicolumn{3}{|c|}{ Banyak Siswa } & \multirow{2}{*}{ Kriteria } \\
\cline { 2 - 4 } & $\begin{array}{c}\text { Skor } \\
\text { dasar }\end{array}$ & $\begin{array}{c}\text { Ulangan } \\
\text { Harian I }\end{array}$ & $\begin{array}{c}\text { Ulangan } \\
\text { Harian II }\end{array}$ & \\
\hline $15-27$ & 0 & 1 & 2 & \multirow{2}{*}{ Tuntas } \\
\hline $28-40$ & 2 & 2 & 4 & \\
\hline $41-53$ & 10 & 3 & 4 & \\
\hline $54-66$ & 10 & 5 & 0 & \\
\hline $67-79$ & 3 & 5 & 8 & \multirow{2}{*}{ Tidak } \\
\hline $80-92$ & 3 & 9 & 4 & Tuntas \\
\hline $93-100$ & 1 & 4 & 7 & \\
\hline$\sum f$ & 29 & 29 & 29 & \\
\hline
\end{tabular}

Dari tabel 3 terlihat bahwa terjadi penurunan jumlah siswa yang memperoleh nilai dibawah KKM $(<67)$. Begitu juga dengan adanya peningkatan jumlah siswa yang memperoleh nilai diatas KKM $(\geq 67)$. Sehingga dapat dikatakan bahwa tindakan yang telah dilakukan berhasil. Artinya dapat disimpulka bahwa penerapan model pembelajaran CPS dapat meningkatkan hasil belajar matematika siswa.

Berdasarkan analisis hasil penelitian, diperoleh kesimpulan tentang aktivitas guru dan siswa. Dari analisis data tentang aktivitas guru dan siswa dapat disimpulkan bahwa aktivitas guru dan siswa pada penerapan model pembelajaran Creative Problem Solving (CPS) sudah sesuai dengan rencana pelaksanaan pembelajaran. Dari analisis data tentang hasil belajar siswa diketahui bahwa terjadi peningkatan jumlah siswa yang mencapai KKM setelah tindakan dibandingkan dengan sebelum tindakan. Persentase ketercapaian KKM pada ulangan harian I adalah $62,07 \%$ (18 orang) dan pada ulangan harian II adalah $65,52 \%$ (19 orang) lebih baik sebelum tindakan yaitu $34,48 \%$ (10 orang).

Beberapa kesalahan siswa pada ulangan harian I adalah untuk indikator 2 (menemukan suku tengah barisan aritmetika) jumlah siswa yang memperoleh nilai $\geq 67$ adalah 17 siswa (58,62\%), artinya ada 12 siswa yang 
belum mencapai KKM, kesalahan siswa yang ditemukan diantarnya adalah kesalahan rumus suku tengah barisan aritmetika dan dalam pengoperasian bilangan. Pada indikator 6 (menemukan suku tengah barisan geometri) jumlah siswa yang memperoleh nilai $\geq 67$ adalah 7 siswa $(24,14 \%)$, artinya ada 22 siswa yang belum mencapai $\mathrm{KKM}$, kesalahan siswa yang ditemukan diantarnya adalah kesalahan rumus suku tengah barisan geometri dan dalam pengoperasian bilangan. Pada indikator (menemukan barisan baru dari penyisipan beberapa suku pada barisan geometri awal) jumlah siswa yang memperoleh nilai $\geq 67$ adalah 15 siswa $(51,72 \%)$, artinya ada 14 siswa yang belum mencapai KKM, kesalahan siswa yang ditemukan diantarnya adalah dalam menuliskan dan menggunakan rumus rasio barisan geometri.

Berdasarkan uraian diatas tidak semua siswa mencapai KKM untuk setiap indikator pada ulangan harian I. Hak ini terjadi karena secara umum siswa kurang teliti mencermati soal yang diberikan. Namun demikian, ketercapaian KKM untuk seluruh indikator pada ulangan harian I sudah tercapai, dari 29 orang siswa terdapat 18 orang siswa yang memeperoleh nilai $\geq 67$ dengan persentasi $62,07 \%$.

Beberapa kesalahan siswa pada ulangan harian II (tabel 11) adalah untuk indikator 1 (menemukan rumus jumlah $n$ suku pertama deret geometri) jumlah siswa yang memperoleh nilai $\geq 67$ adalah 19 siswa $(65,52 \%)$, artinya ada 10 siswa yang belum mencapai KKM, kesalahan siswa yang ditemukandiantarnya adalah karena siswa keliru dalam membedakan Sserta keliru dalam menggunakan rumus padahal pada soal yang ditanya adalah jumlah $n$ suku pertama deret geometri tetapi mereka menggunakan rumus jumlah $n$ suku pertama deret aritmetika. Pada indikator 3 (membuat model matematika dari masalah deret aritmetika) jumlah siswa yang memperoleh nilai $\geq 67$ adalah 17 siswa (58,62\%), artinya ada 12 siswa yang belum mencapai KKM, kesalahan siswa yang ditemukan diantarnya adalah membuat model matematika dan salah dalam menuliskan dan menggunakan rumus. Pada indikator 4 (membuat model matematika dari masalah deret geometri) jumlah siswa yang memperoleh nilai $\geq 67$ adalah 10 siswa $(34,48 \%)$, artinya ada 19 siswa yang belum 
mencapai KKM, kesalahan siswa yang ditemukan diantarnya adalah membuat model matematika dan salah dalam menuliskan dan menggunakan rumus. Pada indikator 5 (menentukan penyelesaian dari masalah yang berkaitan dengan deret aritmetika) jumlah siswa yang memperoleh nilai $\geq 67$ adalah 15 siswa $(51,72 \%)$, artinya ada 14 siswa yang belum mencapai KKM, kesalahan siswa yang ditemukan diantarnya adalah menentukan penyelesaian dari matematika dan salah dalam menuliskan dan menggunakan rumus.

Berdasarkan uraian diatas tidak semua siswa mencapai KKM untuk setiap indikator pada ulangan harian II. Hak ini terjadi karena secara umum siswa kurang teliti mencermati soal yang diberikan. Namun demikian, ketercapaian KKM untuk seluruh indikator pada ulangan harian II sudah tercapai, dari 29 orang siswa terdapat 19 orang siswa yang memeperoleh nilai $\geq 67$ dengan persentasi $65,52 \%$.

Dari analisis hasil penelitian, terjadi peningkatan jumlah siswa yang mencapai KKM sesudah tindakan dibandingkan dengan jumlah siswa yang mencapai KKM sebelum tindakan. Dari pembahasan di atas dapat disimpulkan bahwa hipotesis tindakan yang diajukan dapat diterima kebenarannya. Dengan kata lain penerapan model pembelajaran Creative Problem Solving (CPS) dapat meningkatkan hasil belajar matematika siswa kelas $X$ IPA 1 MAN 2 Model Pekanbaru tahun pelajaran 2009/2010 pada materi pokok barisan dan deret bilangan.

\section{Kesimpulan dan Saran}

Berdasarkan hasil penelitian dan pembahasan diperoleh kesimpulan bahwa penerapan model pembelajaran Creative Problem Solving (CPS) dapat meningkatkan hasil belajar matematika siswa kelas X IPA 1 MAN 2 Model Pekanbaru semester genap tahun pelajaran 2009/2010 pada materi pokok barisan dan deret bilangan. Melalui penelitian yang telah dilakukan, peneliti mengemukakan saran-saran yang berhubungan dengan model pembelajaran Creative problem Solving (CPS)dalam pembelajaran matematika.

1. Guru dapat mengorganisir waktu pembelajaran ini 
13 | al-Khwarizmi, Volume Il, Edisi 2, Oktober 2014, Hal. 1 - 14.

dengan lebih efektif pada tahap pengungkapan gagasan, evaluasi dan seleksi, dan implementasi sehingga pada kegiatan persentasi kelompok dapat terlaksana.

2. Pada tahap pembelajaran CPS yaitu pada tahap pengungkapan gagasan,evaluasi dan seleksi, dan implementasi guru lebih mengarahkan siswa untuk lebih aktif berdiskusi dalam kelompoknya untuk memecahkan masalah yang diberikan.

3. Pada saat siswa berdiskusi dalam kelompok guru lebih memantau dan memberikan bimbingan yang lebih merata kesemua kelompok sehingga siswa mengetahui apa yang harus dikerjakan.

4. Pada saat diskusi kelompok diperoleh ada kelompok yang semua anggota kelompoknya tidak aktif. Sehingga pembagian kelompok dalam CPS ini kedepannya sebaiknya tidak hanya berdasarkan kemampuan akademis dan jenis kelamin tetapi juga harus memperhatikan keaktifan siswa. 


\section{Daftar Pustaka}

Arikunto, S., Suhardjono, dan Supardi., 2008, Penelitian Tindakan Kelas, Bumi Aksara, Jakarta.

Badan Standar Nasional Pendidikan (BSNP)., 2006, Panduan Penyusunan Kurikulum Tingkat Satuan Pendidikan Jenjang Dasan dan Menengah, Jakarta.

Depdiknas., 2006, Kurikulum Tingkat Satuan Pendidikan, Pusat Kurukulum Balitbang Depdiknas, Jakarta.

Pepkin, Karen L., 2004, Creative Problem Solving in Math, Tersedia di: http://hti.math.uh.edu/curriculum/units/2000/02/00.02. 04.pdf

Suyanto., 1997, Pedoman Pelaksanaan Penelitian Tindakan Kelas, Dikti Depdikbud, Yogyakarta.

Wardani, I.G.A.K., 2003, Penelitian Tindakan Kelas, Pusat Penerbitan Universitas Terbuka, Jakarta. 